\title{
RIZIČNI ČIMBENICI EKSTERNALIZIRANIH PONAŠANJA I ODSTUPAJUĆIH NAVIKA HRANJENJA MEĐU ADOLESCENTIMA
}

Goran LIVAZOVIĆ, Silvija RUČEVIĆ Filozofski fakultet, Osijek

UDK: 316.62-053.6:612.39

Izvorni znanstveni rad

Primljeno: 16. 2. 2012.

Cilj ovog istraživanja bio je ispitati relativan doprinos rizičnih čimbenika iz različitih domena (odnosi u obitelii i s vršnjacima te osjećaj pripadnosti školi) u objašnjavanju eksternaliziranih ponašanja (agresivnoga i rizičnoga spolnog ponašanja) i odstupajućih navika hranjenja mladića $(n=429)$ i dievojaka $(n=307)$ iz opće populacije između 15 i 20 godina. Kako bi se ispitala prediktivna snaga ispitivanih varijabli za predviđanje eksternaliziranih ponašanja i odstupajućih navika hranjenja kao kriterijskih varijabli, proveden je niz hijerarhijskih regresijskih analiza. Općenito, kvaliteta odnosa s vršnjacima i osjećaj pripadnosti školi pokazali su se negativnim prediktorima agresivnoga ponašanja i pozitivnim prediktorima odstupajućih navika hranjenja. Nadalje, mladi s boljim školskim uspjehom rjeđe su izvještavali o rizičnom spolnom ponašanju, ali su češće navodili simptome odstupajućih navika hranjenja. Učinak kvalitete odnosa s obitelji na eksternalizirana ponašanja i odstupajuće navike hranjenja posredovan je kvalitetom odnosa s vršnjacima. Nisu utvrđene spolne razlike $u$ rizičnim čimbenicima za različita ponašanja.

Ključne riječi: eksternalizirana ponašanja, odstupajuće navike hranjenja, odnosi s vršnjacima, osjećaj pripadnosti školi, rizični čimbenici

$\triangle \quad$ Goran Livazović, Sveučilište Josipa Jurja Strossmayera u Osiieku, Filozofski fakultet, Odsjek za pedagogiiu, L. Jägera 9, 31000 Osijek, Hrvatska. 
Adolescenti manifestiraju razne oblike eksternaliziranih ponašanja, uključujući agresivno ponašanje (Moffitt i sur., 2001.; Piquero i sur., 2007.) i rizična spolna ponašanja (Guo i sur., 2002.). Osim toga, u novije vrijeme zabilježen je i znatan postotak mladih koji pokazuju neke od simptoma poremećaja hranjenja, odnosno odstupajuće navike hranjenja (npr. Pokrajac-Bulian i sur., 2007.; Wichstrøm, 2000.). No unatoč tome što brojna istraživanja upućuju na preklapanje raznih problema $\mathrm{u}$ ponašanju, posebice $\mathrm{u}$ adolescenciji (Piquero i sur., 2007.; Gillmore i sur., 1991.; McGee i Newcomb, 1992.), malobrojna istraživanja ispitivala su povezanost problema u ponašanju iz raznih domena, kao što su eksternalizirana ponašanja i odstupajuće navike hranjenja (npr. Masten i sur., 2005.). Kao rezultat, još uvijek nije jasno jesu li čimbenici rizika u podlozi javljanja ovih ponašanja jednaki. Dosadašnja istraživanja sugeriraju nisku do umjerenu povezanost između različitih oblika eksternaliziranih ponašanja (npr. apsentizma i vršnjačkoga nasilja) i poremećaja hranjenja/odstupajućih navika hranjenja (Kaltiala-Heino i sur., 2003.; Miotto i sur., 2003.). Na primjer, $\mathrm{u}$ longitudinalnom istraživanju provedenom među adolescenticama od 13 do 15 godina pokazalo se da su zloporaba psihoaktivnih tvari, antisocijalno ponašanje i poremećaji hranjenja povezani (Measelle i sur., 2006.). Slično tome, utvrđena je povezanost između poremećaja hranjenja i agresivnosti među mladima iz opće populacije (Miotto i sur., 2003.). S obzirom na preklapanje koje postoji među ovim dvjema skupinama problema u ponašanju, može se postaviti pitanje postoje li zajednički rizični čimbenici na koje bi se intervencije i preventivni programi trebali usredotočiti.

Do danas su brojna istraživanja potvrdila ulogu kvalitete odnosa s roditeljima i vršnjacima $u$ razvoju i javljanju raznih oblika eksternaliziranih ponašanja, a jedna od teorija koja pokušava objasniti mehanizam njihova djelovanja jest Hirschijeva teorija socijalne kontrole (1969.). Prema ovoj teoriji, problemi u ponašanju posljedica su prekida ili slabljenja veza između pojedinca i društva, uključujući roditelje, vršnjake i školu. Tako, na primjer, istraživanja dosljedno pokazuju da je niska kvaliteta odnosa s roditeljima pozitivno povezana s delinkventnim i agresivnim ponašanjem (npr. Keijsers i sur., 2011.; Piquero i sur., 2007.) te rizičnim spolnim ponašanjem (Henrich i sur., 2006.). Slično tome, osobe dijagnosticirane s nekim od poremećaja hranjenja (npr. bulimija ili anoreksija nervosa) svoje roditelje češće opisuju kao kontrolirajuće i manje brižne $\mathrm{u}$ usporedbi s mladima iz kontrolne skupine (npr. Croll i sur., 2002.; Neumark-Sztainer i sur., 2007.).

U adolescenciji mladi sve više vremena provode s vršnjacima, međutim, mehanizmi u podlozi povezanosti kvalitete 
DRUŠ. ISTRAŽ. ZAGREB GOD. 21 (2012), BR. $3(117)$

STR. 733-752

LIVAZOVIĆ, G., RUČEVIĆ, S.: RIZIČNI ĆIMBENICI.. odnosa s vršnjacima i javljanja raznih oblika eksternaliziranih ponašanja i odstupajućih navika hranjenja još uvijek nisu potpuno jasni. $S$ jedne strane, brojna istraživanja nalaze negativan odnos između kvalitete odnosa s vršnjacima i agresivna ponašanja (npr. Piquero i sur., 2007.) te rizičnih spolnih ponašanja (Manlove i sur., 2008.). Ova istraživanja implicitno sugeriraju da je visoka kvaliteta odnosa s vršnjacima zaštitni čimbenik za javljanje eksternaliziranih ponašanja. Suprotno tome, u nekim je istraživanjima utvrđen pozitivan odnos između procjene kvalitete odnosa s vršnjacima i agresivna ponašanja (npr. Agnew i Brezina, 1997.), dok u drugima nije dobivena povezanost kvalitete odnosa s vršnjacima i razine agresivna ponašanja (Baerveldt i sur., 2003.; Haynie i Osgood, 2005.). Slični rezultati dobiveni su i u istraživanjima rizičnih spolnih ponašanja, npr. dobi prvoga spolnog odnosa, broju seksualnih partnera itd. (npr. Zimmer-Gembeck i sur., 2004.). Općenito, navedena istraživanja pokazuju da kvaliteta odnosa s vršnjacima nije uniformno povezana s eksternaliziranim ponašanjima, a jedno od mogućih objašnjenja jest da su razne razine kvalitete odnosa s vršnjacima (niska/visoka) povezane s raznim oblicima rizičnih ponašanja. Za razliku od istraživanja eksternaliziranih ponašanja, utjecaj kvalitete odnosa s vršnjacima na javljanje poremećaja hranjenja dobio je relativno malo pozornosti (npr. Oliver i Thelen, 1996.). Neka istraživanja sugeriraju da je niska kvaliteta odnosa s vršnjacima (npr. ismijavanje zbog težine) povezana s odstupajućim navikama hranjenja i kod djevojaka (Oliver i Thelen, 1996.) i kod mladića (Haines i sur., 2006.).

Osim roditelja i vršnjaka, škola ima važnu ulogu i u oblikovanju ponašanja adolescenata. Dosadašnja istraživanja pokazuju da su nizak osjećaj pripadnosti školi i slab školski uspjeh povezani s vremenom započinjanja, učestalošću i ozbiljnošću raznih oblika eksternaliziranih ponašanja, kao što su zloporaba psihoaktivnih tvari, apsentizam, agresivno ponašanje te rizično spolno ponašanje (Šakić i sur., 2002.; LaRusso i sur., 2008.; Ajduković i sur., 2009.; Livazović, 2011.). Malobrojna istraživanja odstupajućih navika hranjenja koja su se usredotočila na učinke osjećaja pripadnosti školi i školskog uspjeha daju nekonzistentne rezultate. $S$ jedne strane, istraživanja sugeriraju da su bolji školski uspjeh i privrženost školi povezani sa zdravijim prehrambenim navikama kod djevojaka (BC Adolescent Health Survey, 2003). i mladića (Croll i sur., 2002.). Suprotno tome, $u$ istraživanju Ahrén-Moongove i suradnika (2009.), provedenom među djevojkama, utvrđen je pozitivan odnos između školskog uspjeha i poremećaja hranjenja. Dakle, još se uvijek malo zna o tome jesu li osjećaj pripadnosti školi i školski uspjeh rizični ili zaštitni čimbenici za javljanje odstupajućih navika hranjenja. 
DRUŠ. ISTRAŽ. ZAGREB GOD. 21 (2012) BR. 3 (117)

STR. $733-752$

LIVAZOVIĆ, G. RUČEVIĆ, S.: RIZIČNI ĆIMBENICI..
Iako su brojna istraživanja potvrdila utjecaj roditelja, vršnjaka i osjećaja pripadnosti školi na javljanje i razvoj eksternaliziranih ponašanja i poremećaja hranjenja/odstupajućih navika hranjenja, malobrojna istraživanja istodobno su ispitivala njihovu relativnu važnost (npr. Moffitt i sur., 2001.; Piquero i sur., 2007.). Nadalje, većina istraživanja u kojima se i ispitivala relativna važnost čimbenika iz raznih domena isključivo su se usredotočila na eksternalizirana ponašanja, dok sličnih istraživanja odstupajućih navika hranjenja gotovo i nema. S obzirom na to da se $\mathrm{u}$ adolescenciji prevalencija raznih odstupajućih navika hranjenja povećava (npr. Pokrajac-Bulian i sur., 2007.; Wichstrøm, 2000.), važno je provjeriti imaju li kvaliteta odnosa s roditeljima, vršnjacima i osjećaj pripadnosti školi inhibitorne učinke i na ove oblike ponašanja te u kojoj su mjeri oni slični ili različiti od učinka na razne oblike eksternaliziranoga ponašanja.

Osim toga, istraživanja dosljedno pokazuju da mladići češće manifestiraju razne oblike eksternaliziranih ponašanja, dok su kod djevojaka češći poremećaji prehrane (npr. Wichstrøm, 2000.; Moffitt i sur., 2001.; Pokrajac-Bulian i sur., 2007.; Livazović, 2011.). Stoga bi se moglo pretpostaviti da postoje spolne razlike u rizičnim čimbenicima za ove dvije skupine ponašanja.

S obzirom na nedostatke prethodnih istraživanja, cilj ovog istraživanja bio je ispitati relativan doprinos rizičnih čimbenika iz raznih domena (odnosi u obitelji i s vršnjacima te osjećaj pripadnosti školi) u objašnjavanju eksternaliziranih ponašanja (agresivnoga i rizičnoga spolnog ponašanja) i odstupajućih navika hranjenja. Ispitana je i moderatorska uloga spola.

\section{METODA}

\section{Sudionici i postupak}

U istraživanju je sudjelovalo 736 učenika 2. i 3. razreda srednje škole (gimnazije i strukovne škole), od čega 429 (58,3\%) muškog i $307(41,7 \%)$ ženskog spola. Radi se o višefaznom uzorku, pri čemu je uzorak oblikovan prema podacima Ureda za društvene djelatnosti Osječko-baranjske županije za šk. g. 2009./2010. o učenicima koji pohađaju gimnaziju, trogodišnju i četverogodišnju strukovnu školu iz Osijeka, Belog Manastira, Đakova i Našica. Slojevitost uzorka ujednačena je i proporcionalna koncentraciji škola u odabranoj makroregiji i kreće se unutar 10\% ukupnoga skupa, što se smatra reprezentativnim za ispitanu populaciju (2. i 3. razredi).

Dob je sudionika između 15 i 20 godina, s prosjekom od $15,17(\mathrm{SD}=0,71)$. Prosječna dob mladića $(\mathrm{M}=16,69 ; \mathrm{SD}=0,80)$ i 
DRUŠ. ISTRAŽ. ZAGREB GOD. 21 (2012), BR. $3(117)$

STR. $733-752$

LIVAZOVIĆ, G., RUČEVIĆ, S.: RIZIČNI CIMBENICI. djevojaka ( $M=16,70 ; \mathrm{SD}=0,57)$ gotovo je identična ( $\mathrm{t} 734=0,17$; p>0,05). Njih 100 (57 mladića i 43 djevojke) živi u jednoroditeljskim obiteljima s majkom kao roditeljem skrbnikom. Ispitivanje je bilo anonimno, a provodilo se grupno u trajanju od jednoga školskog sata. Ovdje prikazano istraživanje bilo je dijelom šireg ispitivanja u kojem je upotrijebljen niz upitnika.

\section{Mjerni instrumenti}

Prikupljanje podataka provedeno je anketnim upitnikom konstruiranim za potrebe ovog istraživanja.

\section{Upitnik sociodemografskih podataka}

Za svakog su sudionika prikupljeni podaci o dobi, vrsti škole (gimnazija, umjetnička, trogodišnja strukovna, četverogodišnja strukovna), općem uspjehu u prethodnoj školskoj godini, strukturi obitelji (jednoroditeljska/dvoroditeljska) te obrazovanju majke i oca (VSS, VŠS, SSS, KV i NKV).

\section{Agresivno ponašanje}

Skala agresivna ponašanja sadrži pet čestica kojima se mjeri proaktivna fizička agresija, npr. "Jeste li prijetili fizičkim ozljedama kako biste uzeli novac i sl. od drugih". Skala je nastala po uzoru na Upitnik reaktivno-proaktivne agresije (RPQ; Reactive-Proactive Aggression Questionnaire) (Raine i sur., 2006.). Zadatak sudionika bio je da na skali od pet stupnjeva za svaku česticu procijene koliko su se često ponašali na opisani način, pri čemu 1 označuje da se nikad nisu tako ponašali, a 5 da su se uvijek ili gotovo uvijek tako ponašali. Ukupan rezultat formira se kao prosječna vrijednost odgovora na svim česticama, pri čemu veći rezultat upućuje na izraženije agresivno ponašanje. Faktorskom analizom utvrđena je jednofaktorska struktura skale agresivna ponašanja, a pouzdanost tipa unutarnje konzistencije Cronbach-alfa iznosi $\alpha=0,81$ ( $\alpha$ mladići $=0,79 ; \alpha$ djevojke $=0,81)$.

\section{Skala rizičnoga spolnog ponašanja}

Rizično spolno ponašanje definirano je kao ponašanje koje adolescenta dovodi u rizik za dobivanje spolno prenosivih bolesti, npr. klamidije, AIDS-a ili neželjene trudnoće. Skala je nastala po uzoru na Upitnik samoiskaza rizičnoga i delinkventnoga ponašanja mladih (Ručević i sur., 2009.). Skala sadrži četiri pitanja, a za svaku se tvrdnju odgovara na skali od pet stupnjeva, od "1 - gotovo nikad" do "5 - uvijek ili gotovo uvijek". Ukupan rezultat formira se kao prosječna vrijednost odgovora na svim česticama, a veći rezultat upućuje na rizičnije spolno ponašanje. Utvrđena je jednofaktorska struktura skale, a pouzdanost tipa unutarnje konzistencije (Cronbach-alfa) dobivena u ovom istraživanju zadovoljavajuća je i iznosi $\alpha=0,72$ $(\alpha$ mladići $=0,68 ; \alpha$ djevojke $=0,80)$. 
DRUŠ. ISTRAŽ. ZAGREB GOD. 21 (2012) BR. $3(117)$

STR. $733-752$

LIVAZOVIĆ, G. RUČEVIĆ, S.: RIZIČNI ĆIMBENICI..
Odstupajuće navike hranjenja

Skala odstupajućih navika hranjenja nastala je na temelju Upitnika navika hranjenja (EAT, Eating Attitudes Test; Garner i Garfinkel, 1979.). Skala sadrži pet čestica kojima se mjere različita odstupajuća ponašanja kao što su dijeta, oralna kontrola te zabrinutost hranom (npr. "Namjerno povraćam hranu da bih spriječio/la debljanje" ili "Provjeravam broj kalorija, udjela masti ili ugljikohidrata nekog prehrambenog proizvoda"). Za svaku se tvrdnju odgovara na skali od pet stupnjeva, od "1 - gotovo nikad" do "5 - uvijek ili gotovo uvijek". Ukupan rezultat dobiva se kao prosječna vrijednost odgovora na svim česticama, pri čemu veći rezultat upućuje na izraženije odstupajuće navike hranjenja. Faktorskom analizom utvrđena je jednofaktorska struktura skale odstupajućih navika hranjenja, a pouzdanost tipa unutarnje konzistencije (Cronbach-alfa) prihvatljiva je i iznosi $\alpha=0,72(\alpha$ mladići $=0,68 ; \alpha$ djevojke $=0,80)$.

Nadalje, čestice skala kojima se mjeri kvaliteta odnosa u obitelji i s vršnjacima nastale su po uzoru na Inventar privrženosti roditeljima i vršnjacima (Armsden i Greenberg, 1987.), dok su čestice skale osjećaja pripadnosti školi razvijene za potrebe ovog istraživanja.

\section{Kvaliteta odnosa u obitelji}

Kvaliteta odnosa u obitelji mjerena je sa pet čestica uključujući koliko se osoba osjeća dijelom obitelji, koliko je dobra komunikacija u obitelji te koliko je sudioniku obitelj izvor utjehe i podrške. Zadatak sudionika jest da na skali od pet stupnjeva za svaku česticu procijene koliko se odnosi na njih. Pri tome, 1 znači "gotovo nikad", a 5 "uvijek ili gotovo uvijek". Ukupan rezultat dobiva se kao prosječna vrijednost odgovora na svim česticama, a veći rezultat upućuje na višu kvalitetu odnosa u obitelji. Utvrđena je jednofaktorska struktura skale, dok je pouzdanost tipa unutarnje konzistencije (Cronbach-alfa) zadovoljavajuća i iznosi $\alpha=0,76(\alpha$ mladići $=0,79 ; \alpha$ djevojke $=0,75)$.

\section{Osjećaj pripadnosti školi}

Skala osjećaja pripadnosti školi sastoji se od pet pitanja na koje sudionik odgovara na skali od pet stupnjeva, od "1 - gotovo nikad" do " 5 - uvijek ili gotovo uvijek". Pitanjima se mjeri predanost školi, obrazovne aspiracije, motivacija sudionika te koliko sudionik voli ići u školu. Ukupan rezultat dobiva se kao prosječna vrijednost odgovora na svim česticama, a veći rezultat upućuje na izraženiji osjećaj pripadnosti školi. Utvrđena je jednofaktorska struktura skale osjećaja pripadnosti školi. Pouzdanost tipa unutarnje konzistencije (Cronbach-alfa) dobivena u ovom istraživanju zadovoljavajuća je i iznosi $\alpha=0,83$ $(\alpha$ mladići $=0,82 ; \alpha$ djevojke $=0,83)$. Postavljeno je i pitanje o školskom uspjehu na kraju prethodne školske godine. Korelacija 
DRUŠ. ISTRAŽ. ZAGREB GOD. 21 (2012), BR. $3(117)$

STR. 733-752

LIVAZOVIĆ, G., RUČEVIĆ, S.: RIZIČNI ĆIMBENICI.. između školskog uspjeha i osjećaja pripadnosti školi je, iako niska, značajna i pozitivna $\mathrm{r}=0,27, \mathrm{p}<0,01$ (rmladići $=0,18, \mathrm{p}<0,01$; rdjevojke $=0,39, \mathrm{p}<0,01)$.

\section{Kvaliteta vršnjačkih odnosa}

Kvaliteta vršnjačkih odnosa mjerena je sa četiri čestice. Zadatak sudionika bio je da procijene koliko se dobro slažu s vršnjacima te utjecaj vršnjaka na njihovo ponašanje. Svaka tvrdnja procjenjuje se na skali od pet stupnjeva, i to od "1 - gotovo nikad" do " 5 - uvijek ili gotovo uvijek". Ukupan rezultat dobiva se kao prosječna vrijednost odgovora na svim česticama, pri čemu veći rezultat upućuje na bolje odnose s vršnjacima. Utvrđena je jednofaktorska struktura skale, dok je pouzdanost tipa unutarnje konzistencije (Cronbach-alfa) nešto niža i iznosi $\alpha=0,65$ ( $\alpha$ mladići $=0,70 ; \alpha$ djevojke $=0,64)$.

\section{REZULTATI}

\section{Razlike u kvaliteti odnosa, eksternaliziranih ponašanja i odstupajućih navika hranjenja adolescenata s obzirom na spol}

Mjere simetričnosti pokazale su da distribucije pojavnih oblika problema u ponašanju značajno odstupaju od normalne. Kako bi se poboljšala linearnost i smanjila asimetričnost distribucije, provedene su odgovarajuće statističke transformacije, npr. logaritamska transformacija ili drugi korijen. Statistički postupci (t-test, korelacije i hijerarhijska regresijska analiza) provedeni su na transformiranim podacima. U tablicama su, zbog lakšeg razumijevanja, prikazane aritmetičke sredine i standardne devijacije netransformiranih rezultata (Tabachnick i Fidell, 2007.).

Dobivene su spolne razlike na mjerama kvalitete odnosa s vršnjacima i osjećaju pripadnosti školi, agresivnom i rizičnom spolnom ponašanju te odstupajućim navikama hranjenja. Mladići su postizali viši rezultat na mjerama proaktivnoga agresivnog i rizičnog spolnog ponašanja, dok su djevojke izvještavale o većoj kvaliteti odnosa s vršnjacima te izraženijem osjećaju pripadnosti školi. Osim toga, djevojke su češće izvještavale o odstupajućim navikama hranjenja. Suprotno tome, nije utvrđena značajna razlika između mladića i djevojaka u procjeni kvalitete obiteljskih odnosa. Rezultati analiza prikazani su u Tablici 1.

Veličine učinka za dobivene razlike umjerene su i kreću se od Cohenova $d=0,37$ za školske odnose do Cohenova $d=0,53$ za vršnjačke odnose i agresivno ponašanje. Osjećaj pripadnosti školi kod oba spola procijenjen je najnižim. Nadalje, izraženost agresivnoga i rizičnoga spolnog ponašanja, kao i odstupajućih navika hranjenja, općenito je niska kod oba spola. 
$\rightarrow$ TABLICA 1

Usporedba mladića djevojaka na mierenim varijablama

\begin{tabular}{lrrrrrr}
\hline & \multicolumn{3}{c}{ Mladići } & \multicolumn{3}{c}{ Djevojke } \\
\cline { 6 - 7 } \cline { 5 - 6 } & $\mathrm{M}$ & $\mathrm{SD}$ & & $\mathrm{M}$ & $\mathrm{SD}$ & $\mathrm{t}$ \\
\hline Obiteljski odnosi & 2,83 & 0,39 & 2,79 & 0,42 & 1,26 \\
Vršnjački odnosi & 3,27 & 0,59 & 3,55 & 0,44 & $6,97^{* * *}$ \\
Osjećaj pripadnosti školi & 1,98 & 0,94 & 2,30 & 0,74 & $4,92^{* * *}$ \\
Proaktivno agresivno ponašanje & 1,16 & 0,94 & 0,70 & 0,77 & $7,20^{* * *}$ \\
Rizično spolno ponašanje & 0,63 & 0,83 & 0,33 & 0,56 & $5,59^{* * *}$ \\
Odstupajuće navike hranjenja & 0,27 & 0,62 & 0,54 & 0,72 & $6,76^{* * *}$ \\
\hline
\end{tabular}

${ }^{*} \mathrm{p}<0,05 ;{ }^{* *} \mathrm{p}<0,01 ;{ }^{* *} \mathrm{p}<0,001$

\section{Povezanost kvalitete odnosa i osjećaja pripadnosti školi s pojedinim pojavnim oblicima eksternaliziranih ponašanja i odstupajućih navika hranjenja}

() TABLICA 2

Korelacije između

kvalitete odnosa i

problema u ponašanju

kod oba spola
Kao prvi korak u testiranju hipoteza izračunane su korelacije između procjene kvalitete odnosa s vršnjacima i obitelji, osjećaja pripadnosti školi te pojedinih pojavnih oblika problema u ponašanju. Dobivene su korelacije prikazane zasebno za mladiće i djevojke u Tablici 2.

\begin{tabular}{lllllll}
\hline & 1. & 2. & 3. & 4. & 5. & 6. \\
\hline 1. Obiteljski odnosi & - & $0,26^{* *}$ & $0,18^{* *}$ & $-0,13^{* *}$ & $-0,10^{*}$ & $-0,11^{*}$ \\
2. Vršnjački odnosi & $0,18^{* *}$ & - & 0,08 & $-0,30^{* * *}$ & $-0,08$ & $0,23^{* * *}$ \\
3. Pripadnost školi & $0,21^{* * *}$ & 0,07 & - & $-0,28^{* *}$ & $-0,15^{* *}$ & $0,10^{*}$ \\
4. Proaktivno agresivno ponašanje & $-0,16^{* *}$ & $-0,18^{* *}$ & $-0,21^{* * *}$ & - & $0,27^{* * *}$ & $0,16^{* *}$ \\
5. Rizično spolno ponašanje & $-0,12^{*}$ & $-0,13^{*}$ & $-0,16^{* *}$ & $0,18^{* *}$ & - & 0,04 \\
6. Odstupajuće navike hranjenja & $-0,03$ & $0,14^{*}$ & $0,13^{*}$ & 0,03 & $-0,04$ & - \\
\hline
\end{tabular}

Korelacije za mladiće navedene su iznad dijagonale, a za djevojke ispod dijagonale (označeno kurzivom). ${ }^{*} \mathrm{p}<0,05 ;{ }^{* *} \mathrm{p}<0,01 ;{ }^{* *} \mathrm{p}<0,001$

Dobiveni rezultati pokazuju da je kod oba spola kvaliteta odnosa u obitelji negativno, iako nisko, povezana s pojedinim oblicima eksternaliziranih ponašanja. Za razliku od mladića, kod djevojaka nije utvrđena značajna povezanost između kvalitete obiteljskih odnosa i odstupajućih navika hranjenja. Nadalje, kod oba spola vršnjački odnosi i pripadnost školi negativno su povezani s proaktivnim agresivnim ponašanjem, ali su pozitivno povezani s odstupajućim navikama hranjenja. Kod djevojaka, ali ne i mladića, utvrđena je značajna negativna povezanost između vršnjačkih odnosa i rizičnoga spolnog ponašanja. Usporedbom koeficijenata korelacije Fisherovom r-u-z transformacijom nisu utvrđene značajne razlike u povezanosti ispitivanih varijabli kod mladića i djevojaka. Nadalje, kod oba spola utvrđena je značajna pozitivna povezanost između proaktivnoga agresivnog i spolnoga rizič- 
nog ponašanja, dok je značajna povezanost odstupajućih navika hranjenja utvrđena samo s proaktivnim agresivnim ponašanjem kod mladića.

\section{Spol kao moderator}

Kako bi se ispitala uloga spola kao moderatora efekata kvalitete odnosa u obitelji i s vršnjacima, te osjećaja pripadnosti školi na izraženost pojedinih pojavnih oblika problema u ponašanju, proveden je niz hijerarhijskih regresijskih analiza. Pojedini su oblici ponašanja (agresivno ponašanje, rizično spolno ponašanje i odstupajuće navike hranjenja) uključeni kao kriteriji, dok su kao prediktori u prvom koraku uključene sociodemografske varijable (spol, dob, uspjeh na kraju prethodne školske godine, obrazovanje majke i oca te struktura obitelji - jednoroditeljska ili dvoroditeljska), u drugom odnosi s vršnjacima i u obitelji te osjećaj pripadnosti školi, a u trećem interakcije između spola i mjera kvalitete odnosa (obitelj i vršnjaci) te spola i osjećaja pripadnosti školi. Kako bi se smanjio problem multikolinearnosti, mjere kvalitete odnosa i osjećaja pripadnosti školi centrirane su, odnosno, interakcijski su efekti izračunani kao umnošci devijacijskih rezultata između dvaju skupova nezavisnih varijabli. Rezultati tih analiza prikazani su u Tablici 3, pri čemu su prikazani samo značajni prediktori.

Kvaliteta vršnjačkih odnosa negativan je prediktor agresivna ponašanja, dok je pozitivan odstupajućih navika hranjenja. Slični rezultati dobiveni su i za osjećaj pripadnosti školi. Niža procjena osjećaja pripadnosti školi povezana je s većim agresivnim ponašanjem, dok mladi koji procjenjuju osjećaj pripadnosti školi višim češće izvještavaju o odstupajućim navikama hranjenja. Školski uspjeh značajan je prediktor rizičnoga spolnog ponašanja i odstupajućih navika hranjenja. Pri tome, učenici nižega općeg školskog uspjeha češće pokazuju rizična spolna ponašanja, dok učenici s boljim školskim uspjehom postižu više rezultate na mjeri odstupajućih navika hranjenja.

Nadalje, treba naglasiti da se procjena kvalitete odnosa u obitelji, iako je značajno povezana s gotovo svim indikatorima problema u ponašanju (vidjeti Tablicu 1 ), nije pokazala značajnim prediktorom ni jednog oblika problema u ponašanju. Uključivanjem procjena kvalitete vršnjačkih odnosa beta-koeficijent kvalitete obiteljskih odnosa smanjio se i postao statistički neznačajan, što sugerira postojanje potpune medijacije (Baron i Kenny, 1986.).

Naposljetku treba naglasiti da se ni jedna od interakcija spola i kvalitete odnosa u obitelji i s vršnjacima, kao ni interakcija spola i osjećaja pripadnosti školi, nije pokazala statistički 
značajnom. Drugim riječima, rizični i zaštitni čimbenici jednaki su za mladiće i djevojke.

\begin{tabular}{|c|c|c|c|c|}
\hline & Model & Varijable & $\beta$ & $\begin{array}{l}\mathrm{R}^{2} \\
\text { (značajnost } \\
\text { F omjera za } \\
\text { promjenu } \mathrm{R}^{2} \text { ) }\end{array}$ \\
\hline \multicolumn{5}{|l|}{ Eksternalizirano ponašanje } \\
\hline \multirow{6}{*}{$\begin{array}{l}\text { Proaktivno } \\
\text { agresivno ponašanje }\end{array}$} & \multirow[t]{2}{*}{ 1. korak } & Spol & $-0,28^{* * *}$ & \multirow[t]{2}{*}{$0,09^{* * *}$} \\
\hline & & Obrazovanje majke & $-0,08^{*}$ & \\
\hline & \multirow[t]{4}{*}{ 2. korak } & Spol & $-0,19 * * *$ & \multirow[t]{4}{*}{$0,21^{* * *}$} \\
\hline & & Obrazovanje majke & $-0,09 *$ & \\
\hline & & Vršnjački odnosi & $-0,22 * * *$ & \\
\hline & & Osjećaj pripadnosti školi & $-0,23^{* * *}$ & \\
\hline \multirow[t]{10}{*}{ Rizično spolno ponašanje } & \multirow[t]{4}{*}{ 1. korak } & Spol & $-0,13^{* *}$ & \multirow[t]{4}{*}{$0,13^{* * *}$} \\
\hline & & Dob & $0,14^{* * *}$ & \\
\hline & & Školski uspjeh & $-0,22 * * *$ & \\
\hline & & Obrazovanje oca & $-0,09^{* *}$ & \\
\hline & \multirow[t]{6}{*}{ 2. korak } & Spol & $-0,09^{*}$ & \multirow[t]{6}{*}{$0,16^{* * *}$} \\
\hline & & Dob & $0,13^{* *}$ & \\
\hline & & Školski uspjeh & $-0,20 * * *$ & \\
\hline & & Obrazovanje oca & $-0,10^{*}$ & \\
\hline & & Vršnjački odnosi & $-0,09^{*}$ & \\
\hline & & Osjećaj pripadnosti školi & $-0,08^{*}$ & \\
\hline \multicolumn{5}{|l|}{ Zdravlje } \\
\hline \multirow{6}{*}{$\begin{array}{l}\text { Odstupajuće } \\
\text { navike hranjenja }\end{array}$} & \multirow[t]{2}{*}{ 1. korak } & Spol & $0,21^{* * *}$ & \multirow[t]{2}{*}{$0,08^{* * *}$} \\
\hline & & Školski uspjeh & $0,14^{* * *}$ & \\
\hline & \multirow[t]{4}{*}{ 2. korak } & Spol & $0,24^{* *}$ & \multirow[t]{4}{*}{$0,12^{* * *}$} \\
\hline & & Školski uspjeh & $0,10^{*}$ & \\
\hline & & Vršnjački odnosi & $0,17^{* * *}$ & \\
\hline & & Osjećaj pripadnosti školi & $0,13^{*}$ & \\
\hline
\end{tabular}

(1) TABLICA 3

Rezultati hijerarhijske regresijske analize za pojedine oblike problema u ponašanju
Spol: 0 - mladići, 1 - djevojke

Struktura obitelji: 1 - jednoroditeljska obitelj, 2 - dvoroditeljska obitelj. ${ }^{*} \mathrm{p}<0,05 ;{ }^{* *} \mathrm{p}<0,01 ;{ }^{* *} \mathrm{p}<0,001$

\section{RASPRAVA}

Slično prethodnim istraživanjima, izraženost proaktivnoga agresivnog ponašanja (Ručević i Duvnjak, 2010.; Salmivalli i Nieminen, 2002.) i rizičnoga spolnog ponašanja veća je kod mladića nego djevojaka (Byrnes i sur., 1999.; Ručević, 2010.). U skladu s rezultatima nekoliko studija (npr. Ma i Huebner, 2008.; Livazović, 2011.), djevojke su izvještavale o većoj kvaliteti odnosa s vršnjacima. Nadalje, djevojke su češće izvještavale o odstupajućim navikama hranjenja. Dobivene razlike u skladu su s rezultatima istraživanja provedenih u Hrvatskoj (npr. Pokrajac-Bulian i sur., 2007.) i svijetu (npr. McCrearyi Sasse, 2006.). 
DRUŠ. ISTRAŽ. ZAGREB GOD. 21 (2012), BR. $3(117)$

STR. 733-752

LIVAZOVIĆ, G., RUČEVIĆ, S.: RIZIČNI ĆIMBENICI..
Suprotno prethodnim istraživanjima (npr. Jacobson i Rowe, 1999.; McNeely i sur., 2002.), djevojke su procjenjivale osjećaj pripadnosti školi višim u odnosu na mladiće. Jedan od mogućih razloga dobivenih razlika jest primjena raznih mjera osjećaja pripadnosti školi, kao i fokus na razne aspekte tog konstrukta (Thompson i sur., 2006.).

Nadalje, $\mathrm{u}$ prethodnim istraživanjima, npr. Marmorstein i sur. (2007.), utvrđena je značajna pozitivna povezanost eksternaliziranih ponašanja, odnosno agresivna ponašanja i odstupajućih navika hranjenja kod djevojaka. Suprotno tome, u ovom istraživanju, kao i u onom Slanea i suradnika (2010.), utvrđena je značajna povezanost samo kod mladića. Neka istraživanja pokazuju da su i odstupajuće navike hranjenja i agresivno ponašanje povezani s impulzivnošću, odnosno da je impulzivnost dio disregulacijskoga spektra koji pridonosi javljanju navedenih ponašanja (Diaz-Marsá i sur., 2000.; Kane i sur., 2004.; Peñas-Lledó i sur., 2004.). Slični rezultati utvrđeni su i za rizično spolno ponašanje. Istraživanja također pokazuju da je impulzivnost općenito izraženija kod mladića nego kod djevojaka (npr. Moffitt i sur., 2001.). Dakle, moguće je da je odnos odstupajućih navika hranjenja i agresivna ponašanja kod mladića rezultat izraženije impulzivnosti kod mladića. No treba naglasiti da ovu hipotezu nužno valja provjeriti u budućim istraživanjima, s obzirom na to da ne postoje prethodna istraživanja koja su ispitivala odnos impulzivnosti, agresivna ponašanja i odstupajućih navika hranjenja.

Rezultati ovoga istraživanja pokazuju da je kvaliteta odnosa $\mathrm{s}$ vršnjacima negativan prediktor agresivna ponašanja. Prethodna istraživanja dosljedno pokazuju da je agresivno ponašanje adolescenata povezano s lošijim vršnjačkim odnosima, vršnjačkim odbijanjem, niskim statusom u vršnjačkoj grupi, kao i nižom kvalitetom privrženosti vršnjacima (npr. Crick i sur., 2006.; Salmivalli i sur., 2000.). Longitudinalna istraživanja upućuju na postojanje dvosmjernog odnosa između prihvaćenosti među vršnjacima, kvalitete vršnjačkih odnosa te agresivna ponašanja. Odnosno, ponašanje mlade osobe predviđa vršnjačko prihvaćanje ili odbacivanje, što zauzvrat ima važan utjecaj na oblikovanje budućega agresivnog i prosocijalnog ponašanja u interakcijama s vršnjacima (Newcomb i sur., 1993.; Cillessen i sur., 2000.; Zimmer-Gembeck i sur., 2005.). Slični rezultati utvrđeni su i za rizično spolno ponašanje.

Suprotno očekivanjima, visoka kvaliteta vršnjačkih odnosa pokazala se značajnim prediktorom odstupajućih navika hranjenja. Ovi rezultati dovode u pitanje dosadašnje pretpostavke o zaštitnoj ulozi visoke kvalitete odnosa s vršnjacima za razvoj i javljanje odstupajućih navika hranjenja. Naime, uobičajeno je mišljenje da osjećaj prihvaćenosti od vršnjaka i bolji odnosi s vršnjacima ublažavaju potrebu za konformiranjem idealu mršavosti (npr. Stice i sur., 2002.). No istraživanja tako- 
DRUŠ. ISTRAŽ. ZAGREB GOD. 21 (2012) BR. $3(117)$

STR. $733-752$

LIVAZOVIĆ, G. RUČEVIĆ, S.: RIZIČNI ĆIMBENICI.. đer pokazuju da mladi počinju manifestirati neke od odstupajućih navika hranjenja kako bi ih vršnjaci bolje prihvatili (Oliver i Thelen, 1996.). Slično tome, Crollova i suradnici (2002.) utvrdili su da je prevalencija poremećaja hranjenja veća među djevojkama, koje vršnjačke odnose procjenjuju podržavajućima. Autori dobivene rezultate objašnjavaju time da u vršnjačkim grupama postoji tzv. "norma mršavosti" koja povezuje članove grupe, odnosno članovi konformiranjem toj normi dobivaju potporu svojih vršnjaka (Eisenberg i sur., 2005.). No moguće je i to da vršnjaci pokazuju veću zabrinutost i pružaju više potpore adolescenticama kod kojih su opazili odstupajuće navike hranjenja (npr. povraćanje, prejedanje) (Croll i sur., 2002.). Ukupno uzevši, rezultati ovih istraživanja sugeriraju da utjecaj vršnjaka, neovisno o tome doživljava li se "pozitivno" (npr. podržavanje bulimičnih ponašanja kao načina održavanja željene tjelesne težine) ili "negativno" (npr. ismijavanje težine), ima važnu ulogu u javljanju odstupajućih navika hranjenja (Gerner i Wilson, 2005.; Neumark-Sztainer i sur., 2007.; Schutz i Paxton, 2007.).

U skladu s očekivanjima, osjećaj pripadnosti školi i školski uspjeh pokazali su se značajnim negativnim prediktorima agresivnoga i rizičnoga spolnog ponašanja. Ovi su rezultati u skladu s hipotezom da osjećaj pripadnosti i pozitivni stavovi prema školi djeluju kao zaštitni čimbenici za javljanje društveno neprihvatljivoga i rizičnog ponašanja (Lonczak i sur., 2002.; Menard i Grotpeter, 2011.). Naime, prema nekim autorima (npr. Hirschi, 1969.), mladi koji uspostave pozitivne socijalne odnose sa školom, za razliku od onih kojima to ne uspije, češće manifestiraju prosocijalna ponašanja (npr. pomaganje drugim učenicima) te uspijevaju ostvariti svoj akademski potencijal.

Suprotno tome, osjećaj pripadnosti školi i bolji školski uspjeh pokazali su se značajnim pozitivnim prediktorima odstupajućih navika hranjenja. Iako je odnos poremećaja hranjenja i osjećaja pripadnosti školi već duže u žarištu istraživanja, rezultati nisu posve konzistentni. Na primjer, $\mathrm{u}$ istraživanju Crollove i suradnika (2002.) pozitivan osjećaj pripadnosti školi pokazao se zaštitnim čimbenikom za javljanje poremećaja hranjenja kod mladića, ali ne i djevojaka. Autori izostanak zaštitne funkcije osjećaja pripadnosti školi kod djevojaka objašnjavaju snažnijim utjecajem vršnjaka, pri čemu vršnjaci podupiru odstupajuće navike hranjenja kao prihvatljiv način održavanja težine. Suprotno tome, u istraživanju provedenom među 30500 mladih osoba u Kanadi utvrđeno je da je osjećaj povezanosti sa školom povezan sa zdravijim prehrambenim navikama (BC Adolescent Health Survey, 2003.). Pri tome je kod djevojaka s pozitivnim osjećajem pripadnosti školi prejedanje bilo za trećinu manje, a povraćanje nakon jedenja upola manje nego kod djevojaka kod kojih je privrženost školi bila niska.

Nadalje, u istraživanju Ahrén-Moongove i suradnika (2009.) provedenom u Švedskoj među djevojkama i ženama rođenim 
DRUŠ. ISTRAŽ. ZAGREB GOD. 21 (2012), BR. $3(117)$

STR. 733-752

LIVAZOVIĆ, G., RUČEVIĆ, S.: RIZIČNI ĆIMBENICI.. između 1952. i 1989. godine $(N=13,376)$ utvrđena je značajna povezanost između školskih ocjena i hospitalizacije zbog poremećaja hranjenja (tj. bulimije ili anoreksije). Pri tome, djevojke i žene koje su imale bolji školski uspjeh ujedno su imale i veći rizik za hospitalizaciju zbog poremećaja hranjenja. Moguće je da djevojke s boljim uspjehom pred sebe postavljaju visoke ciljeve te su izložene visokim očekivanjima o uspjehu od svojih roditelja. Suprotno tome, u istraživanju Crollove i suradnika (2002.) utvrđeno je da je školski uspjeh mladića i djevojaka koji su izvještavali o poremećajima hranjenja bio značajno niži u odnosu na školski uspjeh onih koji nisu izvještavali o takvim problemima.

Ukupno uzevši, dobiveni rezultati pokazuju da se u podlozi eksternaliziranih ponašanja i odstupajućih navika hranjenja nalaze isti čimbenici (kvaliteta vršnjačkih odnosa i osjećaj pripadnosti školi), međutim mehanizmi njihova djelovanja različiti su. Jedno od mogućih objašnjenja jest da su ti razni mehanizmi rezultat različite prihvaćenosti određenih ponašanja među vršnjacima. Na primjer, za razliku od odstupajućih navika hranjenja koje su prihvaćene među vršnjacima (npr. Croll i sur., 2002.), mladi koji se ponašaju agresivno često bivaju odbačeni od vršnjaka (npr. Zimmer-Gembeck i sur., 2005.). Stoga bi se u budućim istraživanjima trebalo ispitati konkretno ponašanje, kao i stavovi vršnjaka prema određenim ponašanjima (npr. agresivnom ponašanju i provođenju dijete kao načinu održavanja željene težine). Osim toga, dobiveni rezultati pokazuju da su rizični i zaštitni čimbenici za pojedine oblike problema u ponašanju jednaki kod mladića i djevojaka. Suprotno očekivanjima, kvaliteta odnosa u obitelji nije se pokazala značajnim prediktorom ni jednog od ispitivanih oblika ponašanja. Rezultati hijerarhijske regresijske analize pokazuju da je učinak odnosa $u$ obitelji na probleme $u$ ponašanju posredovan kvalitetom vršnjačkih odnosa. Neki autori sugeriraju da kvaliteta odnosa u obitelji ima važniju ulogu u inhibiciji raznih oblika eksternaliziranih ponašanja od vršnjaka (npr. Formoso i sur., 2000.). No rezultati ovog istraživanja, kao i oni Brooka i sur. (1997.) te Gerrarda i sur. (1999.), pokazuju da su vršnjački odnosi bolji prediktor ponašanja adolescenata nego odnosi u obitelji. Jedno od mogućih objašnjenja jest da u adolescenciji kvaliteta odnosa i prihvaćenost od vršnjaka postaju važniji od odnosa s roditeljima (Criss i sur., 2002.; Windle, 2000.; Wood i sur., 2001.). Drugi autori pak sugeriraju da kvaliteta odnosa s obitelji u adolescenciji počinje indirektno utjecati na ponašanje adolescenta, npr. kroz izbor vršnjaka s kojima će se adolescent družiti (Bamberg i sur., 2001.). No istraživanja također pokazuju da su kvaliteta odnosa s vršnjacima i njihovo mišljenje važniji kod kratkoročnih, manje važnih i manje teških odluka (npr. konzumacija alkohola, spolna ponašanja), dok su odnosi s roditeljima i njihovo miš- 
DRUŠ. ISTRAŽ. ZAGREB GOD. 21 (2012), BR. $3(117)$

STR. $733-752$

LIVAZOVIĆ, G. RUČEVIĆ, S.: RIZIČNI CIMBENICl... ljenje važniji kada je adolescent suočen s teškim i zahtjevnim odlukama (npr. odabir fakulteta) (Galotti i Mark, 1994.).

Iako je istraživanje provedeno na relativno velikom uzorku hrvatskih srednjoškolaca iz nekoliko gradova, ono ima i svojih ograničenja. Istraživanje je provedeno transverzalno i temelji se isključivo na samoprocjenama, kod kojih uvijek postoji rizik davanja socijalno poželjnih odgovora. Osim toga, sudionici se mogu razlikovati u tome razumiju li koja se ponašanja smatraju provođenjem dijete, a koja ne. Provođenjem dijete smatra se svako ponašanje koje uključuje smanjenje porcija, izbacivanje nekih skupina namirnica te preskakanje obroka što mnoge osobe ne znaju (Pokrajac-Bulian i sur., 2007.). Međutim, istraživanja su pokazala da su samoprocjene valjane i pouzdane mjere raznih oblika eksternaliziranih ponašanja (Thornberry i Krohn, 2000.).

Nadalje, $u$ ovom istraživanju nisu uzete $u$ obzir individualne karakteristike adolescenata, kao što su osobine ličnosti ili samopoštovanje, a koje bi mogle utjecati na javljanje pojedinih oblika problema u ponašanju. Na primjer, impulzivnost i traženje uzbuđenja koji su uobičajeno povezani s eksternaliziranim ponašanjem (Piquero i sur., 2007.) pokazali su se i značajnim prediktorima prejedanja (npr., Diaz-Marsá i sur., 2000.). Dakle, uključivanjem individualnih karakteristika dobio bi se uvid u njihovu relativnu važnost u pojavi i razvoju različitih oblika problema u ponašanju, kao i njihov odnos s pojedinim domenama odnosa (obitelj, vršnjaci) i osjećajem pripadnosti školi. Nadalje, istraživanja također pokazuju da važnost odnosa u pojedinim kontekstima varira s obzirom na dob (npr. Windle, 2000.; Wood i sur., 2001.). Stoga bi se njihov utjecaj na pojavu pojedinih oblika problema u ponašanju trebao ispitati i u raznim dobnim skupinama. Osim toga, u budućim istraživanjima trebala bi se ispitati i interakcija kvalitete odnosa u raznim domenama. Tako, na primjer, istraživanja pokazuju da je utjecaj vršnjaka izraženiji kada je odnos adolescent - roditelj manje kvalitetan (npr. Noller, 1994.).

Unatoč nedostacima, rezultati ovog istraživanja pokazuju da su razni oblici problema u ponašanju rezultat, barem djelomično, zajedničkih čimbenika. No rezultati također pokazuju da, ovisno o obliku ponašanja, isti čimbenik može djelovati i kao čimbenik rizika i kao čimbenik zaštite. Ovi rezultati impliciraju da je za planiranje učinkovitih preventivnih programa i provođenje tretmana nužno poznavati mehanizme djelovanja pojedinih čimbenika. Drugim riječima, iako bi se preventivni programi trebali usredotočiti na različite oblike problema u ponašanju, oni bi također trebali uzeti u obzir i specifično djelovanje pojedinih čimbenika, njihov međusobni odnos, kao i odnos sa sociokulturnim kontekstom u kojem se program i tretman provode. 
Agnew, R. i Brezina, T. (1997.), Relational Problems with Peers, Gender, and Delinquency. Youth and Society, 29 (1): 84-111. doi:10.1177/ 0044118X97029001004

Ahrén-Moonga, J., Silverwood, R., Klinteberg, B. i Koupil, I. (2009.), Association of Higher Parental and Grandparental Education and Higher School Grades with Risk of Hospitalization for Eating Disorders in Females. The Uppsala Birth Cohort Multigenerational Study. American Journal of Epidemiology, 170 (5): 566-575. doi:10.1093/aje/kwp166 Ajduković, M., Ručević, S. i Šincek, D. (2009.), Istraživanje rasprostranjenosti rizičnog i delinkventnog ponašanja djece i mladih u urbanim sredinama - Dodatni poticaj za ciljanu prevenciju. Dijete $i$ društvo, 1/2 (10): 27-47.

Armsden, G. i Greenberg, M. (1987.), The Inventory of Parent and Peer Attachment: Individual Differences and Their Relationship to Psychological Well-Being in Adolescence. Journal of Youth and Adolescents, 16 (5): 424-454. doi:10.1007/BF02202939

Baerveldt, C., Van Rossem, R. i Vermande. M. (2003.), Pupils Delinquency and Their Social Networks. A Test of Some Network Assumptions of the Ability and Inability Models of Delinquency. The Netherlands Journal of Social Sciences, 39 (2): 107-125.

Bamberg, J., Toumbourou, J. W., Blyth, A. i Forer, D. (2001.), Change for the BEST: Family Changes for Parents Coping with Youth Substance Abuse. Australian and New Zealand Journal of Family Therapy, 22 (4): 189-198.

Baron, R. M. i Kenny, D. A. (1986.), The Moderator-Mediator Variable Distinction in Social Psychological Research: Conceptual, Strategic and Statistical Considerations. Journal of Personality and Social Psychology, 51 (6): 1173-1182. doi:10.1037//0022-3514.51.6.1173

BC Adolescent Health Survey (2003.), Fact Sheet, http://www.mcs. bc.ca/pdf/school_connections_ahs_3_fs.pdf, učitano: 9. 11. 2011.

Brook, J. S., Whiteman, M., Balka, E. B. i Cohen, P. (1997.), Drug Use and Delinquency: Shared and Unshared Risk Factors in African American and Puerto Rican Adolescents. Journal of Genetic Psychology, 158 (1): 25-39. doi:10.1080/00221329709596650

Byrnes, J. P., Miller, D. C. i Schafer, W. D. (1999.), Gender Differences in Risk Taking: A Meta-Analysis. Psychological Bulletin, 125 (3): 367-383. doi:10.1037//0033-2909.125.3.367

Cillessen, A. H. N., Bukowski, W. M. i Haselager, G. J. T. (2000.), Stability of Sociometric Categories. New Directions for Child and Adolescent Development, 2000 (88): 75-93. doi:10.1002/cd.23220008807

Crick, N. R., Ostrov, J. M. i Werner, N. E. (2006.), A Longitudinal Study of Relational Aggression, Physical Aggression and Children's Social-Psychological Adjustment. Journal of Abnormal Child Psychology, 34 (2): 131-142. doi:10.1007/s10802-005-9009-4

Criss, M. M., Pettit, G. S., Bates, J. E., Dodge, K. A. i Lapp, A. L. (2002.), Family Adversity, Positive Peer Relationships, and Children's Externalizing Behavior: A Longitudinal Perspective on Risk and Resilience. Child Development, 73 (4): 1220-1237. doi:10.1111/1467-8624. 00468 
DRUŠ. ISTRAŽ. ZAGREB GOD. 21 (2012) BR. $3(117)$

STR. 733-752

LIVAZOVIĆ, G. RUČEVIĆ, S.: RIZIČNI ĆIMBENICI..
Croll, J., Neumark-Sztainer, D., Story, M. i Ireland, M. (2002.), Prevalence and Risk and Protective Factors Related to Disordered Eating Behaviors among Adolescents: Relationship to Gender and Ethnicity. Journal of Adolescent Health, 31 (2): 166-175. doi:10.1016/S1054139X(02)00368-3

Diaz-Marsá, M., Carrasco, J. L. i Saiz, J. (2000.), A Study of Temperament and Personality in Anorexia and Bulimia Nervosa. Journal of Personality Disorders, 14 (4): 352-359. doi:10.1521/pedi.2000.14.4.352

Eisenberg, M. E., Neumark-Sztainer, D., Story, M. i Perry, C. (2005.), The Role of Social Norms and Friends' Influences on Unhealthy Weight-Control Behaviors among Adolescent Girls. Social Science and Medicine, 60 (6): 1165-1173. doi:10.1016/socscimed.2004.06.055

Formoso, D., Gonzales, N. A. i Aiken, L. S. (2000.), Family Conflict and Children's Internalizing and Externalizing Behavior: Protective Factors. American Journal of Community Psychology, 28 (2): 175-199. doi:10.1023/A:1005135217449

Galotti, K. M. i Mark, M. C. (1994.), How Do High School Students Structure an Important Life Decision? A Short-Term Longitudinal Study of the College Decision-Making Process. Research in Higher Education, 35 (5): 589-607. doi:10.1007/BF02497089

Garner, D. M. i Garfinkel, P. E. (1979.), The Eating Attitudes Test: An Index of the Symptoms of Anorexia Nervosa. Psychological Medicine, 9 (2): 273-279. doi:10.1017/S0033291700030762

Gerner, B. i Wilson, P. H. (2005.), The Relationship Between Friendship Factors and Adolescent Girls' Body Image Concern, Body Dissatisfaction, and Restrained Eating. International Journal of Eating Disorders, 37 (4): 313-320. doi:10.1002/eat.20094

Gerrard, M., Gibbons, F. X., Zhao, L., Russell, D. W. i Reis-Bergan, M. (1999.), The Effect of Peers' Alcohol Consumption on Parental Influence: A Cognitive Mediational Model. Journal of Studies on Alcohol, 13 (Suppl.): 32-44.

Gillmore, M. R., Hawkins, J. D., Catalano, R. F., Jr., Day, L. E., Moore, M. i Abbott, R. (1991.), Structure of Problem Behaviors in Preadolescence. Journal of Consulting and Clinical Psychology, 59 (4): 499-506. doi:10.1037/0022-006X.59.4.499

Guo, J. C., Chung, I. J., Hill, K. G., Hawkins, J. D., Catalano, R. F. i Abbott, R. D. (2002.), Developmental Relationships between Adolescent Substance Use and Risky Sexual Behavior in Young Adulthood. Journal of Adolescent Health, 31 (4): 354-362. doi:10.1016/S1054-139X (02)00402-0

Haines, J., Neumark-Sztainer, D., Eisenberg, M. E. i Hannan, P. J. (2006.). Weight Teasing and Disordered Eating Behaviors in Adolescents: Longitudinal Findings from Project EAT (Eating Among Teens). Pediatrics, 117 (2): e209-e215. doi:10.1542/peds.2005-1242

Haynie, D. L. i Osgood, D. W. (2005.), Reconsidering Peers and Delinquency: How Do Peers Matter? Social Forces, 84 (2): 1109-1130. doi:10.1353/sof.2006.0018

Henrich, C. C., Brookmeyer, K. A., Shrier, L. A. i Shahar, G. (2006.) Supportive Relationships and Sexual Risk Behavior in Adolescence: An Ecological-Transactional Approach. Journal of Pediatric Psychology, 31 (3): 286-297. doi:10.1093/jpepsy/jsj024 
DRUŠ. ISTRAŽ. ZAGREB GOD. 21 (2012), BR. $3(117)$

STR. 733-752

LIVAZOVIĆ, G., RUČEVIĆ, S.: RIZIČNI ĆIMBENICI..
Hirschi, T. (1969.), Causes of Delinquency, Berkeley, University of California Press.

Jacobson, K. C. i Rowe, D. C. (1999.), Genetic and Environmental Influences on the Relationships between Family Connectedness, School Connectedness, and Adolescent Depressed Mood: Sex Differences. Developmental Psychology, 35 (4): 926-939. doi:10.1037/00121649.35.4.926

Kaltiala-Heino, R., Rissanen, A., Rimpelae, M. i Rantanen, P. (2003.), Bulimia and Impulsive Behaviour in Middle Adolescence. Psychotherapy and Psychosomatics, 72 (1): 26-33. doi:10.1159/000067187

Kane, T. A., Loxton, N. J., Staiger, P. K. i Dawe, S. (2004.), Does the Tendency to Act Impulsively Underlie Binge Eating and Alcohol Use Problems? An Empirical Investigation. Personality and Individual Differences, 36 (1): 83-94. doi:10.1016/S0191-8869(03)00070-9

Keijsers, L., Loeber, R., Branje, S. i Meeus, W. (2011.), Bidirectional Links and Concurrent Development of Parent-Child Relationships and Boys' Offending Behaviour. Journal of Abnormal Psychology, 120 (4): 878-889. doi:10.1037/a0024588

LaRusso, M. D., Romer, D. i Selman, R. L. (2008.), Teachers as Builders of Respectful School Climates: Implications for Adolescent Drug Use Norms and Depressive Symptoms in High School. Journal of Youth and Adolescence, 37 (4): 386-398. doi:10.1007/s10964-007-9212-4

Livazović, G. (2011.), Utjecaj medija na poremećaje u ponašanju adolescenata, Neobjavljena doktorska disertacija, Sveučilište u Zagrebu, Filozofski fakultet, Odsjek za pedagogiju.

Lonczak, H. S., Abbott, R. D., Hawkins, J. D., Kosterman, R. i Catalano, R. F. (2002.), Effects of the Seattle Social Development Project on Sexual Behavior, Pregnancy, Birth, and Sexually Transmitted Disease Outcomes by Age 21 Years. Archives of Pediatrics and Adolescent Medicine, 156 (5): 438-447.

Ma, C. Q, i Huebner, E. S. (2008.), Attachment Relationships and Adolescents' Life Satisfaction: Some Relationships Matter More to Girls than Boys. Psychology in the Schools, 45 (2): 177-190. doi:10.1002/ pits.20288

Manlove, J., Logan, C., Moore, K. A. i Ikramullah, E. (2008.), Pathways from Family Religiosity to Adolescent Sexual Activity and Contraceptive Use. Perspectives on Sexual and Reproductive Health, 40 (2): 105-117. doi:10.1363/4010508

Marmorstein, N. R., von Ranson, K. M., Iacono, W. G. i Succop, P. A. (2007.), Longitudinal Associations between Externalizing Behavior and Dysfunctional Eating Attitudes and Behaviors: A Community-Based Study. Journal of Clinical Child and Adolescent Psychology, 36 (1): 87-94. doi:10.1080/15374410709336571

Masten, A. S., Long, J. D., Roisman, G. I., Burt, K. B., Obradović, J., Roberts, J. M., Boelcke, K. i Tellegen, A. (2005.), Developmental Cascades: Linking Academic Achievement, Externalizing and Internalizing Symptoms over 20 Years. Developmental Psychology, 41 (5): 733-746. doi:10.1037/0012-1649.41.5.733

McCreary, D. R. i Sasse, D. K. (2006.), An Exploration of the Drive for Muscularity in Adolescent Boys and Girls. U: M. Drysdale i B. J. Rye 
DRUŠ. ISTRAŽ. ZAGREB GOD. 21 (2012) BR. $3(117)$

STR. 733-752

LIVAZOVIĆ, G. RUČEVIĆ, S.: RIZIČNI ĆIMBENICI.. (ur.), Taking Sides: Clashing Views in Adolescent Psychology (str. 58-65), New York, McGraw-Hill.

McGee, L. i Newcomb, M. D. (1992.), General Deviance Syndrome: Expanded Hierarchical Evaluations at Four Ages from Early Adolescence to Adulthood. Journal of Consulting and Clinical Psychology, 60 (5): 766-776. doi:10.1037/0022-006X.60.5.766

McNeely, C. A., Nonnemaker, J. M. i Blum, R. W. (2002.), Promoting School Connectedness: Evidence from the National Longitudinal Study of Adolescent Health. Journal of School Health, 72 (4): 138-146. doi:10.1111/j.1746-1561.2002.tb06533.x

Measelle, J. R., Stice, E. i Springer, D. (2006.), A Prospective Test of the Negative Affect Model of Substance Abuse Onset: Moderating Effects of Social Support. Psychology of Addictive Behavior, 20 (3): 225-233. doi:10.1037/0893-164X.20.3.225

Menard, S. i Grotpeter, J. K. (2011.), Peer Influence, Social Bonding, Physical and Relational Aggression. Victims and Offenders, 6 (2): 181-206. doi:10.1080/15564886.2011.557326

Miotto, P., De Coppi, M., Frezza, M. i Preti, A. (2003.), Eating Disorders and Suicide Risk Factors in Adolescents: An Italian Community-Based Study. Journal of Nervous and Mental Disease, 191 (7): 437-443. doi:10.1097/01.NMD.0000081590.91326.8B

Moffitt, T. E., Caspi, A., Rutter, M. i Silva, P. A. (2001.), Sex Differences in Antisocial Behavior: Conduct Disorder, Delinquency, and Violence in the Dunedin Longitudinal Study, Cambridge UK, Cambridge University Press.

Neumark-Sztainer, D. R., Wall, M. M., Haines, J. I., Story, M. T., Sherwood, N. E. i van den Berg, P. A. (2007.), Shared Risk and Protective Factors for Overweight and Disordered Eating in Adolescents. American Journal of Preventive Medicine, 33 (5): 359-369. doi:10.1016/j.ame pre.2007.07.031

Newcomb, A. F., Bukowski, W. M. i Pattee, L. (1993.), Children's Peer Relations: A Meta-Analytic Review of Popular, Rejected, Neglected, Controversial, and Average Sociometric Status. Psychological Bulletin, 113 (1): 99-128. doi:10.1037//0033-2909.113.1.99

Noller, P. (1994.), Relationships with Parents in Adolescence: Process and Outcome. U: R. Montemayor, G. R. Adams i T. P. Gullotta (ur.), Personal Relationships during Adolescence: Advances in Adolescent Development (Vol. 6, str. 37-77), Thousand Oaks, CA, Sage.

Oliver, K. K. i Thelen, M. H. (1996.), Children's Perceptions of Peer Influence on Eating Concerns. Behavior Therapy, 27 (1): 25-39. doi:10. 1016/S0005-7894(96)80033-5

Peñas-Lledó, E., de Dios Fernández, J., i Waller, G. (2004.), Association of Anger with Bulimic and Other Impulsive Behaviours among Non-Clinical Women and Men. European Eating Disorders Review, 12 (6): 392-397. doi:10.1002/erv.588

Piquero, A. R., Farrington, D. P. i Blumstein, A. (2007.), Key Issues in Criminal Career Research, Cambridge UK, Cambridge University Press. doi:10.1017/CBO9780511499494 
DRUŠ. ISTRAŽ. ZAGREB GOD. 21 (2012), BR. $3(117)$

STR. 733-752

LIVAZOVIĆ, G., RUČEVIĆ, S.: RIZIČNI CIIMBENICI.
Pokrajac-Bulian, A., Mohorić, T. i Đurović, D. (2007.), Odstupajuće navike hranjenja, nezadovoljstvo tijelom i učestalost provođenja dijete kod hrvatskih srednjoškolaca. Psihologijske teme, 16 (1): 27-46.

Raine, A., Dodge, K., Loeber, R., Gatzke-Kopp, L., Lynam, D., Reynolds, C., Stouthamer-Loeber, M. i Liu, J. (2006.), The Reactive-Proactive Aggression Questionnaire: Differential Correlates of Reactive and Proactive Aggression in Adolescent Boys. Aggressive Behavior, 32 (2): 159-171. doi:10.1002/ab.20115

Ručević, S. (2010.), Psychopathic Personality Traits and Delinquent and Risky Sexual Behaviors in Croatian Sample of Non-Referred Boys and Girls. Law and Human Behavior, 34 (5): 379-391. doi:10.1007/ s10979-009-9196-6

Ručević, S., Ajduković, M. i Šincek, D. (2009.), Razvoj upitnika samoiskaza rizičnog i delinkventnog ponašanja mladih (SRDP-2007). Kriminologija i socijalna integracija, 17 (1): 1-11.

Ručević, S. i Duvnjak, I. (2010.), Povezanost reaktivne i proaktivne agresije, privrženosti i samopoštovanja adolescenata. Psihologijske teme, 19 (1): 103-121.

Salmivalli, C., Kaukiainen, A. i Lagerspetz, K. (2000.), Aggression and Sociometric Status Among Peers: Do Gender and Type of Aggression Matter? Scandinavian Journal of Psychology, 41 (1): 17-24. doi:10.1111/14679450.00166

Salmivalli, C. i Nieminen, E. (2002.), Proactive and Reactive Aggression in Bullies, Victims, and Bully-Victims. Aggressive Behavior, 28 (1): 30-44. doi:10.1002/ab.90004

Schutz, H. K. i Paxton, S. J. (2007.), Friendship Quality, Body Dissatisfaction, Dieting and Disordered Eating in Adolescent Girls. British Journal of Clinical Psychology, 46 (1): 67-83. doi:10.1348/014466506X11 5993

Slane, J. D., Burt, S. A. i Klump, K. L. (2010.), The Road Less Traveled: Associations between Externalizing Behaviors and Eating Pathology. International Journal of Eating Disorders, 43 (2): 149-160. doi:10.1002/ eat.20680

Stice, E., Presnell, K. i Spangler, D. (2002.), Risk Factors for Binge Eating Onset in Adolescent Girls: A 2-Year Prospective Investigation. Health Psychology, 21 (2): 131-138. doi:10.1037/0278-6133.21.2.131

Šakić, V., Franc, R. i Mlačić, B. (2002.), Samoiskazana sklonost adolescenata socijalnim devijacijama i antisocijalnim ponašanjima. Društvena istraživanja, 11 (2-3): 265-289.

Tabachnick, B. i Fidell, L. (2007.), Using Multivariate Statistics (5th ed.), New York, Pearson.

Thompson, D. R., Iachan, R., Overpeck, M., Ross, J. G. i Gross, L. A. (2006.), School Connectedness in the Health Behavior in School-Aged Children Study: The Role of Student, School, and School Neighborhood Characteristics. Journal of School Health, 76 (7): 379-386. doi:10.1111/ j.1746-1561.2006.00129.x

Thornberry, T. P. i Krohn, M. D. (2000.), The Self-Report Method of Measuring Delinquency and Crime. U: U.S. National Institute of Ju- 
DRUŠ. ISTRAŽ. ZAGREB GOD. 21 (2012) BR. $3(117)$

STR. $733-752$

LIVAZOVIĆ, G. RUČEVIĆ, S.: RIZIČNI ĆIMBENICI.. stice (ur.), Measurement and Analysis of Crime and Justice: Criminal Justice Series (Vol. 4, str. 33-83), Washington, DC, National Institute of Justice.

Wichstrøm, L. (2000.), Predictors of Adolescent Suicide Attempts: A Nationally Representative Longitudinal Study of Norwegian Adolescents. Journal of the American Academy of Child and Adolescent Psychiatry, 39 (5): 603-610. doi:10.1097/00004583-200005000-00014

Windle, M. (2000.). Parental, Sibling, and Peer Influences on Adolescent Substance Use and Alcohol Problems. Applied Developmental Science, 4 (2): 98-110. doi:10.1207/S1532480XADS0402_5

Wood, M. D., Vinson, D. C. i Sher, K. J. (2001.), Alcohol Use and Misuse. U: A. Baum, T., Revenson i J. Singer (ur.), The Handbook of Health Psychology (str. 281-318), Hillsdale, NJ, Erlbaum.

Zimmer-Gembeck, M. J., Geiger, T. C. i Crick, N. R. (2005.), Relational and Physical Aggression, Prosocial Behavior, and Peer Relations: Gender Moderation and Bidirectional Associations. The Journal of Early Adolescence, 25 (4): 421-452. doi:10.1177/0272431605279841

Zimmer-Gembeck, M. J., Siebenbrunner, J. i Collins, W. A. (2004.), A Prospective Study of Intra-Individual and Peer Influences on Adolescents' Heterosexual Romantic and Sexual Behaviour. Archives of Sexual Behavior, 33 (4): 381-391. doi:10.1023/B:ASEB.0000028891.16654.2c

\section{Externalizing Behaviors and Eating Disorder Risk Factors in Adolescents}

Goran LIVAZOVIĆ, Silvija RUČEVIĆ

Faculty of Philosophy, Osijek

The current study examined the relative contribution of risk factors from different domains (i.e. family, peers and school) in the explanation of externalizing behaviors (i.e. proactive aggressive behavior and risky sexual behavior) and disordered eating in a community sample of boys $(n=429)$ and girls $(n=307)$, aged 15-20. In order to examine the predictive value of examined variables on types of externalizing behaviors and disordered eating as criterion variables, several hierarchical regression analyses were performed. Generally, it was found that the quality of peer relationships and school affiliation were negative predictors of proactive aggressive behavior and positive predictors of disordered eating. Furthermore, adolescents with higher academic achievements were less likely to engage in risky sexual behavior, but reported more disordered eating behaviors. The quality of peer relationship mediated the effect of the family relationship quality on externalizing behaviors and disordered eating. There were no gender differences in the risk factors for different behaviors.

Keywords: externalizing behaviors, disordered eating, peer relationships, school affiliation, risk factors 